\title{
WestVirginiaUniversity
}

THE RESEARCH REPOSITORY @ WVU

Graduate Theses, Dissertations, and Problem Reports

2019

\section{Persistence of Undergraduate Women in STEM through TIMSI}

Heather L. Henderson

West Virginia University, heather.henderson@hsc.wvu.edu

Follow this and additional works at: https://researchrepository.wvu.edu/etd

Part of the Educational Psychology Commons

\section{Recommended Citation}

Henderson, Heather L., "Persistence of Undergraduate Women in STEM through TIMSI" (2019). Graduate Theses, Dissertations, and Problem Reports. 7435.

https://researchrepository.wvu.edu/etd/7435

This Dissertation is protected by copyright and/or related rights. It has been brought to you by the The Research Repository @ WVU with permission from the rights-holder(s). You are free to use this Dissertation in any way that is permitted by the copyright and related rights legislation that applies to your use. For other uses you must obtain permission from the rights-holder(s) directly, unless additional rights are indicated by a Creative Commons license in the record and/ or on the work itself. This Dissertation has been accepted for inclusion in WVU Graduate Theses, Dissertations, and Problem Reports collection by an authorized administrator of The Research Repository @ WVU.

For more information, please contact researchrepository@mail.wvu.edu. 
Graduate Theses, Dissertations, and Problem Reports

2019

Persistence of Undergraduate Women in STEM through TIMSI

Heather L. Henderson

Follow this and additional works at: https://researchrepository.wvu.edu/etd

Part of the Educational Psychology Commons 
Persistence of Undergraduate Women in STEM through TIMSI

Heather Lysbeth Henderson

Dissertation submitted to the College of Education and Human Services

at West Virginia University

in partial fulfillment of the requirements for the degree of

Doctor of Education in

Educational Psychology

M Cecil Smith, Ph.D., Chair

Paul R. Hernandez, Ph.D.

Karen Rambo-Hernandez, Ph.D.

Natalie J. Shook, Ph.D.

Reagan Curtis, Ph.D. (proxy)

Department of Learning Sciences and Human Development

Morgantown, West Virginia

2019

Keywords: Gender, STEM, Retention, TIMSI, Goal Congruity

Copyright 2019 Heather Lysbeth Henderson 


\section{Abstract \\ Persistence of Undergraduate Women in STEM through TIMSI \\ Heather Lysbeth Henderson}

There is a need to increase the persistence of women in science careers. This study focuses on undergraduate women majoring in or interested in science. Despite interest early on in their academic careers, women are leaving STEM at higher rates than other fields. Through the framework of the Tripartite Integration Model of Social Influence (TIMSI), this study explores psychosocial factors leading to integration in science careers. 484 undergraduate women from 9 universities in the Colorado/Wyoming Front Range and the Carolinas were recruited into this study and surveyed through 8 waves of data collection. A model building process was performed using HLM to study the impact of efficacy, identity, community values, and agentic and communal values on the persistence of undergraduate women in science over time. Results indicate a significant quartic change over time in persistence for undergraduate women, with initially high persistence intentions that steadily drop each semester until leveling out in their final year of undergraduate studies. Women with strong science identities and strong scientific community values begin with even higher persistence intentions. Over time, women with higher scientific community values show greater declines in persistence. Additionally, over time, women who perceive science careers as allowing agentic values have lesser declines in persistence. And women who endorse communal values have greater declines in persistence. Implications for future research include the need to further study the relationship between communal and agentic values regarding the TIMSI framework and the need to target interventions toward building a more diverse notion of what the scientific community values. 


\section{Dedication}

To my grandparents, Margy June and Ray Merlin Henderson, who instilled a love of learning early on and always insisted that "the one thing people can never take away from you is your education". And to the amazing mentors I have had over the years: Ronald Iannone, Patricia Obenauf, Wanda Stegall, Nancy Vandett, Vicki Holt, John McKay, Kate Milutin, and Linda Alexander. And especially to Cecil, Karen, and Paul. I love you all. 


\section{Acknowledgements}

I have been an exceptional graduate student over the years; exceptional in the sense that I have had to rely heavily on the support of my mentors. In many ways, I am quite sure I have been a nuisance. Dr. Dale Niederhauser, thank you for cleaning up my administrative messes and sending me to Cecil. Dr. M Cecil Smith, thank you for the intellectual conversations, your constant encouragement, your delightful sense of humor, and the wisdom to connect me with Karen and Paul. Dr. Karen Rambo-Hernandez, thank you. You were there through the coursework; you were there through the research experiences; and you were there through the tough days. Thank you for seeing me as more than a student. Dr. Paul R. Hernandez, thank you. For four years you have trained me and prepared me. Through all of my silly questions and my tendency to try things without asking how, you have always been patient. For nurturing my desire to learn about research, I am truly grateful. Thank you for always finding the right balance between pushing me to take care of myself and pushing me to work on my studies. You have invested so much toward molding me into who I am today and who I will be tomorrow. There are no words for the gratitude I feel. Dr. Natalie Shook, thank you for asking questions that pushed me to consider additional perspectives. Dr. Malayna Bernstein, your compassion inspires me. Dr. Brittany Bloodhart, thank you for being there whenever I reached out. Dana Musick, thank you for always taking care of the details. Dr. Reagan Curtis, thank you for finding a path to switch me to educational psychology. Your support will have a lifelong impact.

To my care team: surgical oncologist, Dr. Nezar Jrebi, WVU; stroke neurologist, Dr. Muhammad M. Alvi, WVU; neurosurgeon, Dr. Christopher P. Cifarelli, WVU; radiation oncologist, Dr. Paul B. Renz, WVU; radiation oncologist, Dr. Todd Tenenholz, WVU; cardiologist, Dr. Christopher M. Bianco, WVU; internist, Dr. Matthew F. Muldoon, UPMC; 
interventional cardiology surgeon, Dr. Jay S. Giri, Penn Medicine; nephrologist, Dr. Debbie Cohen, Penn Medicine; my sunshine, Robin Neubauer, RN; Penn Medicine; disease management coordinator, Doanna Cupp-Settimio, WVU; physical therapist, Tracy Rice, WVU; and my amazing internist who goes above and beyond to make all the right connections for my care, Dr. Nadia Khan, WVU, thank you. Without each of you, I would not exist today. Literally. 


\section{Table of Contents}

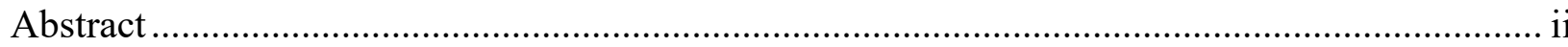

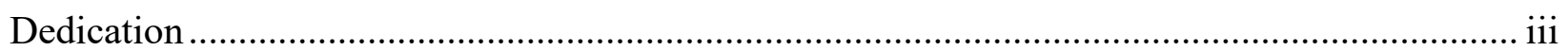

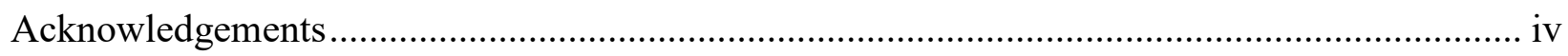

Persistence of Undergraduate Women in STEM through TIMSI................................................

Integration into the Scientific Community......................................................................................

Merging TIMSI and Value Congruity Theories on Integration into STEM ……………………....... 5

Personal value orientations influencing science integration. ........................................................... 6

The Current Study .........................................................................................................................

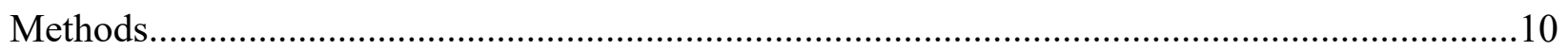

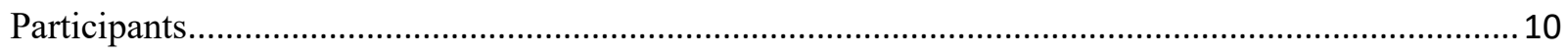

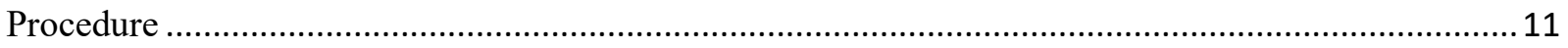

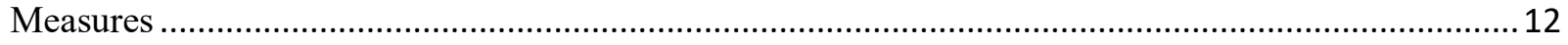

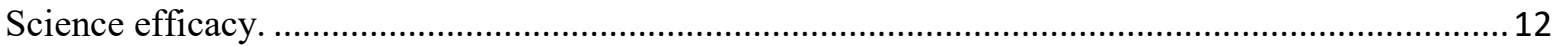

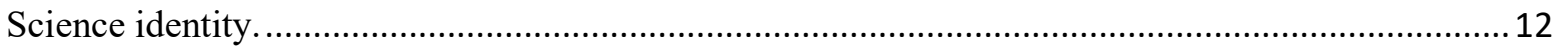

Scientific community values........................................................................................... 13

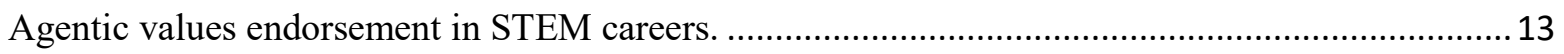

Communal values endorsement in STEM careers. ..................................................................... 13

Perceived agentic value affordance of STEM careers. ……....................................................... 13

Perceived communal value affordance of STEM careers............................................................... 14

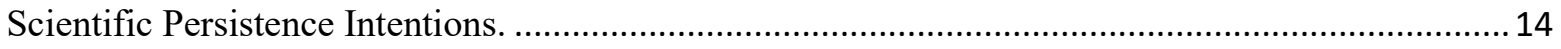

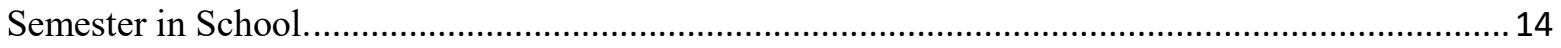

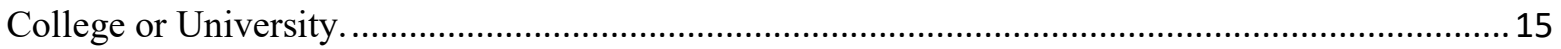

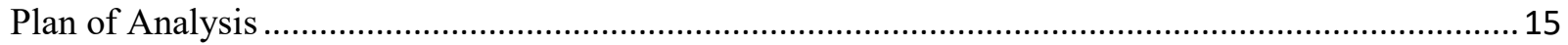

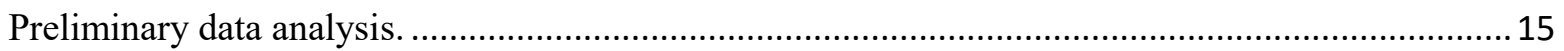

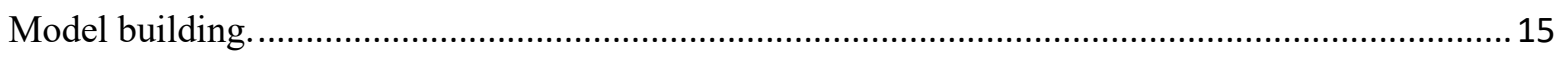

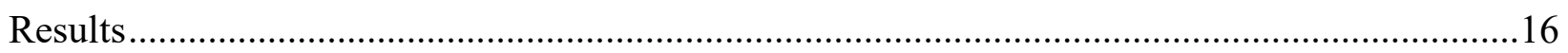

RQ1: How do scientific career persistence intentions change over time for undergraduate women in

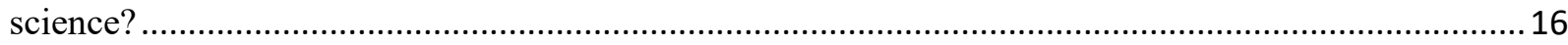

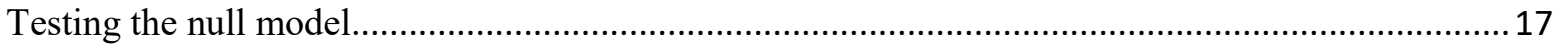

Testing linear and curvilinear growth models......................................................................... 17

The best fit time model ........................................................................................................... 18 
RQ2: To what extent do orientation measures (science efficacy, science identity, scientific community values, agentic values, and communal values) predict initial scientific persistence intentions?

RQ3: To what extent do orientation measures (science efficacy, science identity, scientific community values, agentic values, and communal values) predict scientific persistence intentions over time? ...... 19

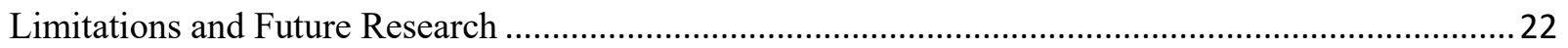

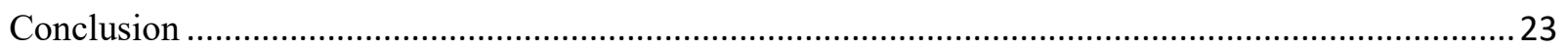

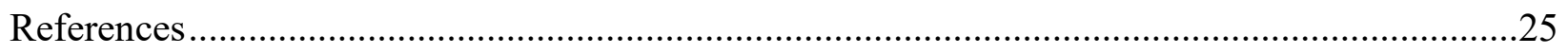

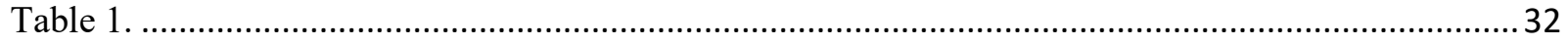

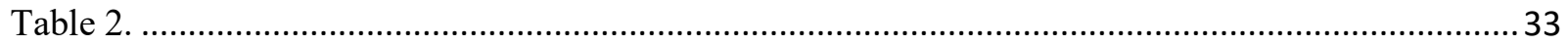

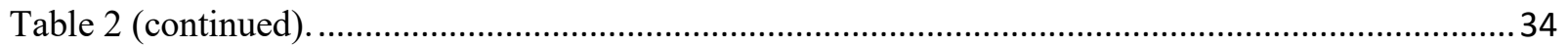

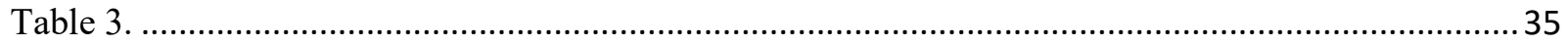

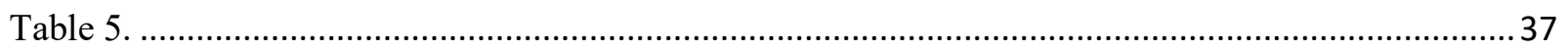

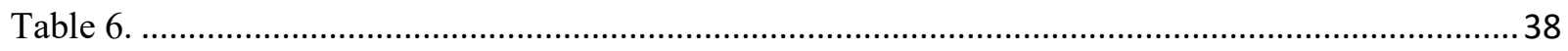

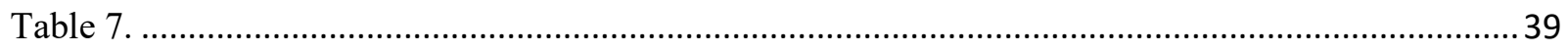

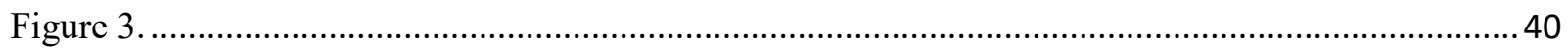


Running head: PERSISTENCE OF WOMEN IN STEM

\section{Persistence of Undergraduate Women in STEM through TIMSI}

There is a continued global push for an increase in both the number of scientists and the diversity of the composition of the science, technology, engineering, and mathematics (STEM) workforce (National Science Board [NSB], 2018). A workforce which does not match the diversity of the population as a whole is absent of the perspectives and talent of which the missing piece is comprised. Nationally, the United States recognizes it is not likely to meet its own research goals without a workforce that is more inclusive and compromised of members representative of the population at large (Nielsen, Alegria, Börjeson, Etzkowitz, Falk-Krzesinski, Joshi, \& Schiebinger, 2017; Snyder, Dillow, \& Hoffman, 2009; President's Council of Advisors on Science and Technology [PCAST], 2012).

In the U.S., more than half of college students that start in a STEM major do not finish in STEM and among students who complete a baccalaureate STEM degree, more than half switch to non-STEM pursuits in graduate school or the workforce (Chen, 2009; Lowell, Salzman, Bernstein, \& Henderson, 2009). Student attrition from many STEM degree and career pathways is even greater among first-generation students, underrepresented racial and ethnic minorities (URMs), and women (Snyder, Dillow, \& Hoffman, 2009; Kokkelenberg and Sinha, 2010; Shaw and Barbuti, 2010). Despite having an early collegiate interest in scientific careers, women are simply not choosing the option to stay on the STEM pathway or to remain in the academic system at numbers comparable to men (Chen, 2013; National Science Foundation [NSF], 2019; Glass, Sassler, Levitte, \& Michelmore, 2013, Shauman, 2017). Despite having nearly equal numbers of males and females successfully completing science courses at elementary and secondary institutions and nearly equal numbers of males and females entering college to study in STEM fields, as academic levels increase (undergraduate through graduate school) women are 
leaving science at exponentially higher rates than their male counterparts (Hill, Corbett, \& St. Rose, 2010). Compared to women in other professions, women leave STEM careers at a rate $30 \%$ higher and women are $165 \%$ more likely to leave STEM pathways if they have an advanced degree (Glass et al., 2013). In addition, marriage makes women 84\% more likely to exit STEM careers (Glass et al., 2013). In this article we will explore psychological processes related to the integration of women into the scientific community and subsequent persistence of women in science careers.

\section{Integration into the Scientific Community}

As the United States strives to create a diverse workforce, it is vital to understand the process of integrating into the scientific community so that institutions of higher education can create an environment conducive to integration (Nielsen et al., 2017). Rooted in Herbert Kelman's (2006) model of social influence, the Tripartite Integration Model of Social Influence (TIMSI; Estrada, Woodcock, Hernandez, \& Schultz, 2011) looks at the ways individuals integrate into the larger social system, specifically in the context of the scientific academy. While it is acknowledged that there are many social integration theories, the TIMSI model has been selected as the foundation for this study due to the universal adaptability across social systems that Kelman's theory posits. Using Kelman's three processes (compliance, identification, and internalization of values), the TIMSI models how individuals meet the demands of the scientific academy (social system) that is influencing them. For an individual to be motivated toward scientific pursuits, the TIMSI provides three possible orientations (rule, role, and value) toward the scientific academy (Estrada et al., 2011). Although an individual may have more than one orientation toward science pursuits, the three orientations (rule, role, 
and value ) are intercorrelated, while remaining uniquely predictive of integration into the academic social system (Estrada et al., 2011).

Rule orientation toward the scientific academy can be measured by self-efficacy, which develops over time by an individual complying with the rules and norms of behavioral expectations in academia (i.e. completing homework, passing exams, participating in undergraduate research experiences). Rule orientation is validated and strengthened when members already in the scientific community give approving feedback to the individual who is following the rules. Role orientation can be measured by scientific identity that develops as an individual takes on the roles of the scientific community. As an individual's behavior matches the expectations for roles of members in the scientific community, the community will likely include the individual in increasingly complex roles, thus strengthening their integration into the community. Roles are more than a set of tasks to be completed; they are part of an individual's self-concept and define their relationships within the system. Value orientation can be measured with scientific community values that develop as an individual integrates the beliefs of the scientific community as their own (Estrada et al., 2011). Integration into a social system can occur by internalizing system values. When an individual is influenced by the values of a social system, they begin to exhibit behaviors that support the shared values. As shared values increase, integration is strengthened.

Figure 1 depicts a simplified model of TIMSI. Self-efficacy, identity, and values predict persistence intentions (scientific integration), which in turn predicts distal outcomes such as degree attainment and enrollment in graduate school. 


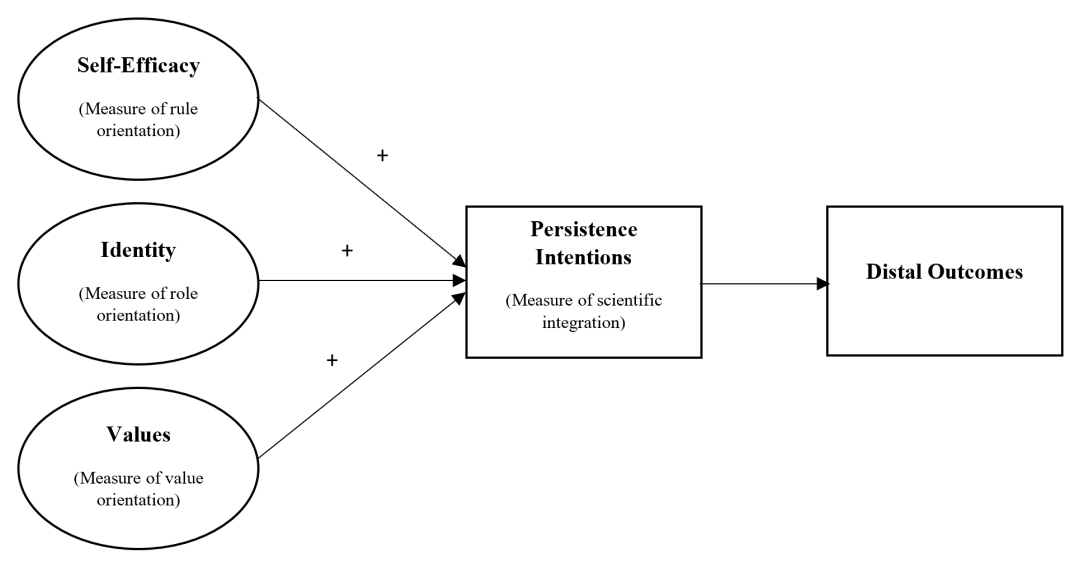

Figure 1. A simplified model of TIMSI depicting the effects of rule, role, and value orientations on scientific integration and eventual distal outcomes.

TIMSI studies to date indicate that scientific self-efficacy for URMs is significantly correlated with integration into science; yet, efficacy loses its status as a unique predictor of integration when identity and values are added to the model (Estrada et al., 2011). More precisely, efficacy has been shown to be predictive of integration for undergraduate URM students early in their academic careers. In contrast, efficacy has not been predictive for URM students in their third or fourth years of undergraduate studies (Estrada et al., 2011 Estrada, Hernandez, \& Schultz, 2018). A growing body of research suggests that efficacy may be predictive of short-term integration, rather than long-term (Estrada et al., 2018). Research exploring possible developmental effects on the relationship between self-efficacy and integration into the scientific community could provide a clearer picture of when efficacy impacts persistence. For example, efficacy might have a significant effect on persistence in early stages of undergraduate academic studies, but as confidence in one's ability to be successful in coursework is achieved third- and fourth- year students may rely more heavily on integrating through the development of identity or community values. 
TIMSI results have shown identity to be uniquely predictive of integration for undergraduates; additionally, identity has a significant mediation effect on distal outcomes through persistence intentions (Estrada et al., 2011). For URMs, science identity positively and uniquely predicts integration in the form of pursuit of a science career as far as four years after graduation (Estrada et al., 2018). Exploring how identity affects the persistence of women will help us to understand if women are integrating into science careers because they feel they are successfully taking on the roles of career scientists.

TIMSI results have shown scientific community values to be predictive of integration for undergraduates; additionally, scientific community values have a significant mediation effect on distal outcomes through persistence intentions and a direct effect on applying to graduate school (Estrada et al., 2011). Scientific community values also positively predict URM pursuit of STEM careers (Estrada et al., 2018). While scientific community values and identity have been shown to be unique predictors of integration for URM students, both male and female, research has not yet focused exclusively on how the TIMSI model applies to undergraduate women.

\section{Merging TIMSI and Value Congruity Theories on Integration into STEM}

Barriers to integrating into science careers. Researchers have explored the barriers to women persisting in science through multiple theoretical perspectives. Findings have indicated significant barriers impacting women's integration in science careers: discouragement from advisors, a chilly environment with limited role models, a lack of sense of belonging, feelings of isolation, a competitive environment that is in opposition to women's preferences for collaboration, and balancing work/family life (Bernstein \& Russo, 2007; Cabay, Bernstein, Rivers \& Fabert, 2018; Fabert \& Bernstein, 2009; Clancy, Lee, Rodgers, \& Richey, 2017; Lippa, 1998; and Herrmann, Adelman, Bodford, Graudejus, Okun, \& Kwan, 2016). Diekman, Clark, 
Johnston, Brown, \& Steinberg (2011) provide evidence that these barriers alone do not explain the discrepancy between the persistence of women in science and women in other high-level professions facing work/family balance concerns. Instead, they have turned to agentic and communal values to explain how women in science careers face unique barriers to persistence.

Personal value orientations influencing science integration. Conflicts between agentic (self-oriented) and communal (other-oriented) values- often referred to as agentic and communal goals- can pose a challenge for integration into the scientific community as women are more likely than men to exhibit communal values, and women are more likely to engage in science to attain communal goals (Eagly, Diekman, Johannesen-Schmidt, \& Koenig, 2004; Pohlmann, 2001; Smith, Brown, Thoman, \& Deemer, 2015; Thoman, Arizaga, Story, Soncuya, \& Smith, 2014). Goal congruity theory asserts that individuals are motivated to pursue careers that provide attainable goals that are congruent with the individual's personal values (Diekman et al., 2011; Diekman \& Steinberg, 2013; Diekman, Weisgram, \& Belanger, 2015; Brown, Thoman, Smith, \& Diekman, 2015). Within goal congruity theory, there are two central types of goal affordances, or values that attract individuals to STEM: communal and agentic (Diekman et al., 2011). An individual's perceived affordances reflect whether a career, in this case a career in STEM, will allow the individual to achieve their personal goals (Brown et al., 2015). In addition to explaining how pursuit of careers can be motivated, goal congruity theory seeks to explain how conflict results when an individual acts outside of the prescribed roles of their gender (Eagly \& Karau, 2002). Socially prescribed gender roles provide the framework for women's expected behavior as they pursue their personal values (Diekman \& Eagly, 2008). For women that wish to pursue communal values, an acceptance of the stereotype that STEM is masculine and does not allow one to engage in activities consistent with communal values will lead to disinterest in the 
pursuit of STEM (Diekman et al., 2011). Whether women endorse agentic or communal values, they may struggle with gender role expectations that either conflict with personal and family life (Cabay et al., 2018; Fabert \& Bernstein, 2009) or conflict with integrating into an academic system that continues to be perceived as agentic in nature (Glass et al., 2013; Gibbs \& Griffin, 2013). Agentic and communal values have not yet been looked at considering the overall social influence model of integration.

\section{The Current Study}

The current study focuses solely on undergraduate women in science, as evidence indicates career persistence changes over time for this population with many women choosing to leave the STEM pathway. To better understand the integration of women into STEM careers, this study seeks to expand upon the TIMSI model by looking for the unique effects of previously tested rule, role, and value orientation indicators on the persistence of undergraduate women in STEM. Specifically, this study tests measures of science efficacy, science identity, and scientific community values on persistence (See Figure 2). Based on previous results (Estrada et al., 2011; Woodcock, Hernandez, Estrada, \& Schultz, 2012; Estrada et al., 2018), this study hypothesizes that science identity and scientific community values will positively and uniquely predict persistence for women in STEM. The study also hypothesizes that science efficacy will be positive and significantly correlated with persistence, with the caveat it may not be a unique 
predictor when identity and values are included in the predictive model.

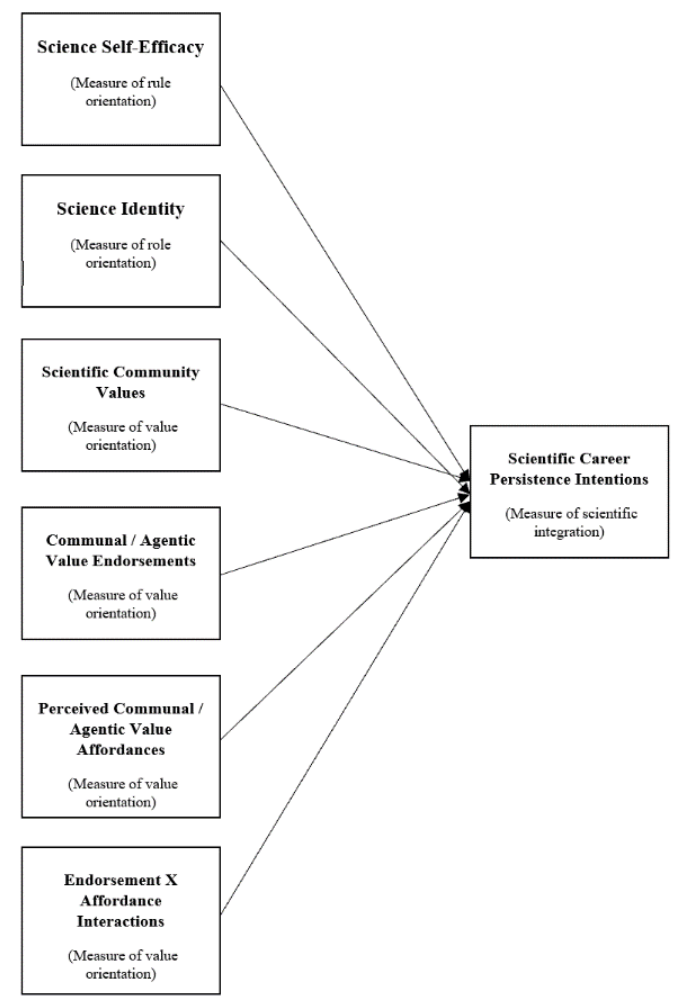

Figure 2. The current study narrows its focus to rule, role, and value orientation measures on persistence intentions of undergraduate women in STEM.

This study then explores whether communal and agentic values predict persistence in STEM. As a yet to be explored part of value orientation in the TIMSI model, communal and agentic values, particularly communal values, might have a significant effect on integration into the scientific community for women. This study has adapted the TIMSI model to include communal and agentic values as an additional aspect of value orientation toward integration into science (see Figure 2). Goal congruity theory states that a lack of congruity between endorsed and perceived values leads to disinterest in pursuing goals (Diekman et al., 2011). For women who endorse communal values and see science careers as not affording those values, this indicates the pursuit of a science career is less likely. Based on goal congruity theory and the 
likelihood of women valuing communal goals (Pohlmann, 2001; Smith et al., 2015; Thoman et al., 2014; Diekman et al., 2011; Diekman \& Steinberg, 2013; Diekman, Weisgram, \& Belanger, 2015; Brown et al., 2015), this study predicts that perceived communal affordance values would positively predict persistence in science. This study also predicts that agentic value endorsement will positively predict integration into science as science is often perceived to afford agentic goals (Eagly \& Karau, 2002; Diekman \& Eagly, 2008). This study also tests the congruity between endorsed values and affordances to explore the interaction effects on persistence in science.

Finally, the current study explores whether the relationship between science efficacy, science identity, and scientific community values and persistence in a science career changes as students matriculate toward their degree completion. While not uniquely predictive of persistence when included in the full TIMSI model, efficacy is significantly associated with persistence; furthermore, cross-sectional analyses of students at different levels of their academic careers, has revealed a need to explain if efficacy is uniquely predictive of persistence at different stages in the integration process (Estrada et al., 2011). For example, will efficacy impact first-year students more than fourth-year? It is possible that efficacy will change in importance over time as those who feel confident in their abilities may move away from a rule orientation yet continue to strengthen their integration by adopting another orientation. This study hypothesizes that orientation measures will vary in their effects on persistence based on a woman's point in her academic career. Not all constructs were measured at all time points for the current study; therefore, this study will look specifically at the effect of constructs on change in persistence intentions over time.

Research questions include: 
RQ1: How do scientific career persistence intentions change over time for undergraduate women in science?

RQ2: To what extent do orientation measures (science efficacy, science identity, scientific community values, agentic values, and communal values) predict initial scientific persistence intentions?

RQ3: To what extent do orientation measures (science efficacy, science identity, scientific community values, agentic values, and communal values) predict scientific persistence intentions over time?

\section{Methods}

\section{Participants}

The total sample in the overall study consisted of 484 undergraduate women selfidentified as having an interest in STEM (see Appendix, Table 1). During the fall semesters of 2015 and 2016, female STEM majors were recruited in two regions including five universities in the Colorado/Wyoming Front Range (Colorado College, Colorado State University, Metropolitan State University of Denver, University of Colorado - Boulder, and University of Wyoming) and four universities in the Carolinas (North Carolina A\&T University, North Carolina State University, University of North Carolina -Charlotte, and University of South Carolina). At the time of recruitment, participants were primarily in their first year (51.4\%) and second year (46.9\%) of college. A majority of participants were of European descent (69.6\%), with additional representation from African (11.6\%), Native American/Pacific Islander/First Nation (11.2\%), Latina (8.9\%), Asian (7.4\%), and other (1.7\%) descent. Twenty-six percent of participants had a family income of less than $\$ 50,000$ and $28.1 \%$ had family incomes over $\$ 100,000$. The women in this study were tracked from the first through the fourth year of 
PERSISTENCE OF WOMEN IN STEM

college as enrolled undergraduates. Women were not tracked into work or graduate school for this study.

\section{Procedure}

Students were recruited into this study in two cohorts, first in the fall of 2015 and second in the fall of 2016, through face-to-face announcements in introductory STEM courses, campus flyers, and email obtained through registrars, departments, or faculty. To participate in the longitudinal study, students completed an IRB approved informed consent form, and then completed a brief online recruitment survey. Students received a $\$ 5$ gift card for their participation in the survey. The initial study, named the Analysis of Women's Advancement, Retention, and Education in Science (AWAREs), was used to identify students who met the inclusion criteria of identifying as female, majoring in or interested in STEM. First- and secondyear undergraduate students were then invited to participate in the study. The current study comes out of a larger study focused on a mentoring intervention called Promoting Geoscience Research, Education, \& Success (PROGRESS).

To date, eight waves of surveys have been conducted each fall/spring semester, beginning with the fall of 2015 and ending with the spring of 2018 for our primary data analysis. Followup surveys include measures of science efficacy, science identity, science community values, agentic and communal values (endorsements and affordances), and intentions to pursue a scientific research career. Using the tailored panel management (TPM) approach (Estrada, Woodcock, \& Schultz, 2014), components of consistency, credibility, communication, and compensation are employed to keep response rates high. Across the 8 waves of data collection, the study had a consistently high average response rate ( 80\%). Communication regarding survey participation is clearly defined for participants during the AWAREs survey administration. For 
this study, a nominal gift of a $\$ 10$ electronic gift card was given to participants for each administration of the survey. Participants had the choice to select their preferred gift card option.

\section{Measures}

Scales for science efficacy, science identity, and scientific community values were administered during all waves of data collection. Scales for communal and agentic values and affordances were measured during waves 3 through 8 .

Science efficacy. Science efficacy was measured with a three-item short form of the science self-efficacy scale (Chemers, Zurbriggen, Syed, Goza, \& Bearman, 2011). Participants rated the extent of their confidence with each of the following statements: "I am confident that I can use technical science skills (use of tools, instruments, and/or techniques," "I am confident that I can use scientific language and terminology," and "I am confident that I can generate a research question to answer" on a seven-point Likert scale from not at all confident (1) to absolutely confident (7). Scale scores were derived by taking the average of the three items. Scale scores have high internal consistency reliability (Cronbach's $\alpha=.96$; Chemers et al., 2011).

Science identity. Science identity was measured with a three-item short form of the science identity scale (Chemers et al., 2011). Participants rated their agreement with each of the following statements: "In general, being a scientist is an important part of my self-image," I have a strong sense of belonging to the community of scientists," and "I have come to think of myself as a 'scientist"' on a seven-point Likert scale from strongly disagree (1) to strongly agree (7). Scale scores were derived by taking the average of the three items. Scale scores have high internal consistency reliability (Cronbach's $\alpha=.89$; Chemers et al., 2011). 
Scientific community values. Scientific community values were measured with a fouritem short form of the scientific community values scale (Estrada et al., 2011). Participants rated the extent to which each of the following statements is like them: "A person who thinks discussing new theories and ideas between scientists is important", "A person who thinks it is valuable to conduct research that builds the world's scientific knowledge", "A person who feels discovering something new in the sciences is thrilling", and "A person who thinks that scientific research can solve many of today's world challenges" on a seven-point Likert scale from not at all like me (1) to very much like me (7). Scale scores have high internal consistency reliability (Cronbach's $\alpha=.85$; Estrada et al., 2011).

Agentic values endorsement in STEM careers. Agentic value endorsement was measured with a three-item short form of the goal endorsement scale. Participants rated the extent to which the following values are personally important "achievement, individualism, and competition" on a seven-point Likert scale from not at all important (1) to extremely important (7). Scale scores have high internal consistency reliability (Cronbach's $\alpha=.83$; Diekman et al., 2011).

Communal values endorsement in STEM careers. Communal value endorsement was measured with a three-item short form of the goal endorsement scale. Participants rated the extent to which the following values are personally important "serving community, working with people, and helping others" on a seven-point Likert scale from not at all important (1) to extremely important (7). Scale scores have high internal consistency reliability (Cronbach's $\alpha=$ .83; Diekman et al., 2011).

Perceived agentic value affordance of STEM careers. Perceived agentic value affordance was measured with a three-item short form of the perceived goal affordance of STEM 
careers scale. Participants rated the extent to which a career in science, technology, engineering, or mathematics would fulfill the following goals: "achievement, individualism, and competition" on a seven-point Likert scale from not at all fulfilled (1) to extremely fulfilled (7). Scale scores have high internal consistency reliability (Cronbach's $\alpha=.79$; Diekman, Brown, Johnston, \& Clark, 2010).

Perceived communal value affordance of STEM careers. Perceived communal value affordance was measured with a three-item short form of the perceived goal affordance of STEM careers scale. Participants rated the extent to which a career in science, technology, engineering, or mathematics would fulfill the following goals: "serving community, working with people, and helping others" on a seven-point Likert scale from not at all fulfilled (1) to extremely fulfilled (7). Scale scores have high internal consistency reliability (Cronbach's $\alpha=.80$; Diekman, Brown, Johnston, \& Clark, 2010).

Scientific Persistence Intentions. Persistence intentions was measured with a two-item short form of the Intentions to Pursue a Scientific Research Career Scale (Woodcock et al., 2012; Woodcock, Hernandez, \& Schultz, 2015). Participants rated how likely they are to pursue a scientific career with the following statements: "To what extent do you plan to pursue a sciencerelated research career?" and "To what extent do you plan to pursue a science-related graduate degree?" on a seven-point Likert scale from definitely will not (1) to definitely will (7). The combined items were averaged to create a single scale score of persistence. Scale scores have high internal consistency reliability (Cronbach's $\alpha=.74$; Woodcock et al., 2015).

Semester in School. At the time of recruitment, semester in school was measured with a single item using the following statement "What is your current year in college?" $(0=$ fall semester first year, $1=$ spring semester first year, $2=$ fall semester sophomore year, $3=$ spring 
semester sophomore year, $4=$ fall semester junior year, $5=$ spring semester junior year, $6=$ fall semester senior year, and 7= spring semester senior year).

College or University. At the time of recruitment, college or university was measured with a single item using the following statement "Which university do you attend?" $(0=$ Not a student, 1= Colorado College, 2= Colorado State University, 3= Metropolitan State University of Denver, 4= North Carolina A\&T University, 5= North Carolina State University, 6= University of Colorado - Boulder, $7=$ University of North Carolina - Charlotte, $8=$ University of South Carolina, 9= University of Wyoming, and 10= Other (Please Specify).

\section{Plan of Analysis}

Preliminary data analysis. Descriptive statistics were analyzed using IBM SPSS Statistics version 25 (see Appendix, Tables 2 and 3). Prior to testing the research questions, missing data analysis, outlier analysis, and assumption testing for hierarchical linear modeling, including linearity, normality, and homoscedasticity tests was performed. Outliers were not severe and distributional assumptions held (Snijders \& Bosker, 2012; Garson, 2014).

Model building. To test our hypotheses, we conducted a series of analyses in a hierarchical linear modeling framework using HLM v.7 (Bryk \& Raudenbush, 2002). To identify how scientific career persistence intentions change over time for undergraduate women in science, we used a model-building approach (testing linear and curvilinear effects) to select the best fit model for the change in persistence intentions over time. Second, to test how orientation measures predict initial persistence intentions for undergraduate women in science, we tested three sets of variables (TIMSI, agentic and communal values, and interaction effects) on the Level -2 intercept. Third, to test how orientation measures predict persistence intentions of undergraduate women in science over time, we tested three sets of variables (TIMSI, agentic 
and communal values, and interaction effects) on the Level -2 slope of spring semester of first year. Level -2 measures predicting the intercept and linear slope were only kept in the model when they showed significant variability at Level -2 .

To determine the best fitting models, three information criteria measures were calculated: chi-square difference, Akaike information criterion (AIC), and Bayesian information criterion (BIC) (Garson, 2020; See Appendix, Table 6). When comparing nested models, if the chisquare difference was non-significant, the model was rejected. If the chi-square difference was statistically significant, models were accepted if they added at least one statistically significant parameter. If none of the added parameters were statistically significant, then the model was ultimately rejected despite a significant chi-square test. For non-nested models, the AIC and BIC were used. If the AIC and BIC were in agreement that the model was a better fit, the model was accepted. As with the chi-square square test, models were rejected that added only statistically non-significant parameters.

\section{Results}

\section{RQ1: How do scientific career persistence intentions change over time for undergraduate women in science?}

To determine the best fit model for time, eight competing nested models were tested (see Table 4). Descriptive statistics showed means for persistence intentions having four shifts over the total time points collected (see Appendix, Figure 3). Shifts in persistence intentions included a downward trend from the spring semester of year one to fall semester of year two. A slight rise in intentions occurred between fall and spring of year two. Spring of year 2 to fall of year three saw a slight downward trend. And from fall of year 3 to spring of year 4 persistence intentions plateaued. Therefore, the tested models included linear, quadratic, cubic, and/or quartic builds. 
Testing the null model. To determine the amount of variance that lies between and within participants, the intraclass correlation (ICC) was estimated using the following Level 1 null model

$$
\text { PERSISTENCE }_{\mathrm{ti}}=\pi_{0 \mathrm{i}}+\mathrm{e}_{\mathrm{ti}}
$$

where PERSISTENCE $t i$ is the intention to persist score for student $i$ at time $t, \pi_{0 \mathrm{i}}$ is the intercept of the regression equation predicting average persistence intentions for student $i$ across all time points, and $\mathrm{e}_{\mathrm{ti}}$ is the deviation of student $i$ at time $t$ from his or her average score across all time points. The Level 2 equation is

$$
\pi_{0 \mathrm{i}}=\beta_{00}+\mathrm{r}_{0 \mathrm{i}}
$$

with a combined Level 1 and 2 equation of

$$
\text { PERSISTENCE } \mathrm{ti}_{\mathrm{i}}=\beta_{00}+\mathrm{r}_{0 \mathrm{i}}+\mathrm{e}_{\mathrm{ti}}
$$

Examination of the fixed effect $\left(\beta_{00}=5.60\right.$, maximum is 7$)$ indicates that the mean intention score across all students and time points was statistically significantly different from zero (see table). The calculated ICC shows the estimates of between-student variance $\left(\tau_{00}=\right.$ $1.21)$ and within-student variance $\left(\sigma^{2}=0.83\right)$. In our sample, the ICC is .59 , which indicates that $59 \%$ of the variability in scores lies between students and $41 \%$ of the variability lies within students over time.

Testing linear and curvilinear growth models. Once the null hypothesis was rejected, time models were built by sequentially adding linear, quadratic, cubic, and quartic parameters to the null model. For each time parameter, models initially included random effects. Models with random effects which were determined to be statistically non-significant were removed to keep the final model as parsimonious as possible (see Appendix, Table 4). 
The best fit time model. To evaluate the curvilinear change in persistence intentions scores over time, Model 8 estimated linear, quadratic, cubic, and quartic time. The Level-1 and Level-2 equations for the quartic growth model including random effects for linear time (M8) are included in Appendix, Table 4.

The fixed effects $\left(\beta_{00}, \beta_{10}, \beta_{20}, \beta_{30}\right.$, and $\left.\beta_{40}\right)$ show that the parameter estimates were statistically significant for all parameters except $\beta_{20}$. The intercept $\left(\beta_{00}=6.04\right)$ is relatively high which indicates that initial persistence intentions were high. The instantaneous linear growth slope is negative $\left(\beta_{10}=-0.41\right)$ which indicates that student persistence intentions dropped over time. These findings are consistent with declines in underrepresented minority populations, and undergraduate students interested in science (Schultz et al., 2011). The cubic growth slope was relatively small and negative $\left(\beta_{30}=-0.06\right)$ indicating that a decline of student intentions returned over time. The quartic growth slope was very small and positive $\left(\beta_{40}=0.01\right)$ indicating a slight rise in persistence intentions over time. The random effect for linear time was statistically significant.

The time model predicted means for persistence intentions were closely aligned with actual means (see Appendix, Figure 3).

RQ2: To what extent do orientation measures (science efficacy, science identity, scientific community values, agentic values, and communal values) predict initial scientific persistence intentions?

To determine the best fit models for the extent that orientation measures predict initial scientific persistence intentions (intercept models) and the extent that orientation measures predict scientific persistence changes over time (linear slope models), six competing nested 
models were tested (see Appendix, Table 5: Intercept and Slope Models). Model 13 was determined to be the best fit final model (see Appendix, Table 6).

After identifying the best predictive model, an examination of the parameter estimates revealed that the Level 1 fixed effects for identity $\left(\beta_{02}=0.51\right)$ and scientific community values $\left(\beta_{03}=0.44\right)$ were statistically significant. The effects of efficacy, agentic and communal endorsements and affordances $\left(\beta_{01}, \beta_{04}, \beta_{05}, \beta_{06}\right.$, and $\left.\beta_{07}\right)$ on the intercept were all statistically non-significant.

RQ3: To what extent do orientation measures (science efficacy, science identity, scientific community values, agentic values, and communal values) predict scientific persistence intentions over time?

The best fitting model also provided insights into factors that moderated linear growth of persistence intentions over time. Specifically, the results indicated that the Level 2 TIMSI fixed effects for efficacy and identity $\left(\beta_{11}\right.$ and $\left.\beta_{12}\right)$ were statistically non-significant. The Level 2 fixed effects for scientific community values $\left(\beta_{13}=-0.05\right)$ were negatively statistically significant. The effect of scientific community values on the linear slope indicates a higher association with scientific community values will have a greater decline in persistence intentions each semester enrolled in school. The Level 2 TIMSI fixed effects for efficacy and identity ( $\beta_{11}$ and $\left.\beta_{12}\right)$ were statistically non-significant. The Level 2 agentic and communal values effects were statistically significant for agentic affordance values $\left(\beta_{14}\right)$ and communal endorsement values $\left(\beta_{17}\right)$.

Communal affordance values and agentic endorsement values are statistically non-significant. The effect of agentic affordance values on the linear slope $\left(\beta_{14}=0.10\right)$ is positive and indicates a higher association with agentic affordance values will have less decline in persistence intentions for each semester enrolled in school. The effect of communal endorsement values on the linear 
slope $\left(\beta_{17}=-0.05\right)$ is negative and indicates a higher association with communal endorsement values will have greater decline in persistence intentions for each semester enrolled in school. The random effect for linear time was statistically significant.

\section{Discussion}

Initial intentions to pursue science careers were relatively high for the undergraduate women in the present study. Initial intent was even greater for women with increased science identity and increased scientific community values. While the persistence intentions of undergraduate women in the present study steadily decreased over time, the decline was lessened by women with higher levels of perceived agentic affordances. Both endorsement of communal values and endorsement of scientific community values made greater declines in persistence intentions over time.

\section{Integration into the Scientific Community}

Our first research question looked at how scientific career persistence intentions change over time for undergraduate women in science. The goal of the present study was not to convert women to science career pursuit, but rather to understand how women that already have an interest change in their persistence intentions over time.

During the spring semester of their first year of school, women began with a relatively high intent to pursue a science career. The study population consisted of students already pursuing science and science-related degrees, so it is not a stretch to expect them to begin with relatively high persistence intentions. However, the linear growth trajectory was -0.41 , meaning that for each additional semester of school, a woman lost on average .41 units in her persistence intentions (on a 7-point scale). Using linear, quadratic, cubic, and quartic growth trajectories, by Wave 8 (4 years after initial recruitment), the modeled student intention dropped to 4.60 . While 
the overall growth trajectory was negative, this is consistent with previous research indicating a steady decline in persistence intentions over time for students interested in science (Schultz, Hernandez, Woodcock, Estrada, Chance, Aguilar, \& Serpe, 2011).

\section{Value Orientations}

The positive impact of science identity on the persistence of students in science is tested across multiple theoretical frameworks including goal theory (Hernandez, Schultz, Estrada, Woodcock, \& Chance, 2013), identity theory (Stets, Brenner, Burke, \& Serpe, 2017), and TIMSI (Estrada et al., 2011). The present study affirms that students with strong science identities have higher initial intentions to pursue science careers. Contrary to study expectations, science identity did not significantly impact persistence intentions for undergraduate women across semesters when agentic and communal values were added to the intercept in the full model.

The results for the present study indicate undergraduate women with strong scientific community values have higher initial intentions to pursue science careers and that undergraduate women with higher scientific community values have an even greater decline in their persistence intentions for each semester enrolled. It is interesting that while scientific community values have an initial positive effect on persistence intentions, it shifts to a negative effect over time. This suggests caution when analyzing the impact of value orientations and implies a need to focus attention based on the point at which a female student is in their academic career. What initially attracts a woman to science may not continue attraction later in her career. Limited female role models, negative faculty interactions, and institutions that do not support social agency have been shown to negatively impact women and belongingness in the scientific community (Herrmann et al., 2016; Clancy et al., 2017; Griffin, Bennett, Staples, Robinson, \& Gibbs, 2015; Garibay, 2018). 


\section{Barriers and Personal Value Orientations}

TIMSI studies to date have focused on scientific community values as a measure of value orientation and integration into a science career. The present study suggests additional value orientations (agentic and communal) toward persistence for undergraduate women in science. The present study found that female students who perceive science careers as providing agentic value affordances have slightly lower declines in persistence intentions over time. These findings echo sentiments found in other studies suggesting that women who lean toward agentic values are more persistent when they perceive science careers as allowing them to express their agentic values (Brosi, Spörrle, Welpe, \& Heilman, 2016; Rudman \& Glick, 2001).

The results in the present study indicate that female students who endorse communal values have even greater declines in persistence intentions over time. This suggests the need to explore interventions targeted at increasing beliefs that science affords communal values for undergraduate women in science. Studies have already shown exposure to communal opportunities in science and exposure to scientist exemplars engaged in communal opportunities increases beliefs that science affords communal values which in turn predicts increased science career interest (Fuesting, Diekman, \& Hudiburgh, 2017; Clark, Fuesting, \& Diekman, 2016).

\section{Limitations and Future Research}

The present study adds to the TIMSI framework by exploring how undergraduate women in science persist as they matriculate through their academic careers. It also extends the TIMSI framework to explore additional value orientations.

The present study, however, is limited by a population comprised of mostly majority status students. This limits the ability to look at other factors that impact the experiences and intentions of specific groups such as undergraduate women of color, LGBTQ women, first- 
generation women, and so forth. Additional studies exploring the intricate relationships between parameters such as these and the impact they have on value orientations for women who wish to pursue scientific careers could likely give valuable insight on the integration barriers women face. It would also be of benefit to have future research focus on other populations for comparison.

This study is also limited to women during their undergraduate years. Additional longitudinal research needs to explore the relationships between value orientations and persistence intentions for women across their career trajectory from undergraduate through advanced careers stages. The TIMSI model is ideal for this exploration as it is based on theory that extends across social systems and would transition between academic training and workforce integration.

The present study is limited by not including potential controls and moderators of the effects with measures such as institution, specific fields of study, and demographics which could lead to variability in the effects by regional differences, culture differences, or field specific differences. In addition, PROGRESS was not accounted for as a control variable.

The present study is underpowered to detect variability in higher order growth trends. The ability to test measures against the quadratic, cubic, and quartic growth slopes in future research would provide a more detailed picture of the effects of parameters on persistence intentions as they occur over time.

For future research, all constructs should be measured on all occasions to respond to the strengthening and weakening of predictor effects over time.

\section{Conclusion}

There is value in exploring how women integrate into science careers as they matriculate through their academic programs. This study provides evidence that the endorsement of 
communal values and the endorsement of scientific community values increases the likelihood that a woman will choose to remove herself from the STEM pathway over time. And although women majoring in science programs with relatively higher levels of role and value orientations (scientific community) have a higher initial intent to pursue science, these orientations did not predict increased persistence over time in the final model. For women that perceive science careers as providing attainment of agency goals, there is a slightly lower decline in pursuing science over time. The scientific community must continue to find ways to integrate women that endorse communal values in its pursuit of a diverse workforce. 


\section{References}

Bernstein, B. L., \& Russo, N.F. (2007). Career paths and family in the academy: progress and challenges. In Work, Life, and Family Imbalance: How to Level the Playing Field. Edited by Michele Antoinette Paludi and Presha E. Neidermeyer. Westport: Praeger Press, pp. 89-119.

Brosi, P., Spörrle, M., Welpe, I., \& Heilman, M. (2016). Expressing pride: Effects on perceived agency, communality, and stereotype-based gender disparities. Journal of Applied Psychology, 101(9), 1319-1319.

Brown, E., Thoman, D., Smith, J., \& Diekman, A. (2015). Closing the communal gap: The importance of communal affordances in science career motivation. Journal of Applied Social Psychology, 45(12), 662-673. doi:10.1111/jasp.12327

Bryk, A., \& Raudenbush, S. (2002). Hierarchical linear models: Applications and data analysis methods (2nd ed., Advanced quantitative techniques in the social sciences, 1). London: SAGE publications.

Cabay, M., Bernstein, B., Rivers, M., \& Fabert, N. (2018). Chilly climates, balancing acts, and shifting pathways: What happens to women in stem doctoral programs? Social Sciences, 7(2), 23-23. doi:10.3390/socsci7020023

Chemers, M. M., Zurbriggen, E. L., Syed, M., Goza, B. K., \& Bearman, S. (2011). The role of efficacy and identity in science career commitment among underrepresented minority students. Journal of Social Issues, 67(3), 469-491. https://doi.org/10.1111/j.15404560.2011.01710.x

Chen, X. (2009). Students who study science, technology, engineering, and mathematics (STEM) in postsecondary education (NCES 2009-161). National Center for Education 
Statistics, Institute of Education Sciences, U.S. Department of Education. Washington, DC. Retrieved from https://nces.ed.gov/pubs2009/2009161.pdf

Chen, X. (2013). STEM Attrition: College Students' Paths Into and Out of STEM Fields (NCES 2014-001). National Center for Education Statistics, Institute of Education Sciences, U.S. Department of Education. Washington, DC.

Clancy, K., Lee, K., Rodgers, E., \& Richey, C. (2017). Double jeopardy in astronomy and planetary science: Women of color face greater risks of gendered and racial harassment. Journal of Geophysical Research: Planets, 122(7), 1610-1623. doi:10.1002/2017JE005256

Clark, E., Fuesting, M., \& Diekman, A. (2016). Enhancing interest in science: Exemplars as cues to communal affordances of science. Journal of Applied Social Psychology, 46(11), 641-654. doi:10.1111/jasp.12392

Diekman, A., Brown, E., Johnston, A., \& Clark, E. (2010). Seeking congruity between goals and roles: A new look at why women opt out of science, technology, engineering, and mathematics careers. Psychological Science, 21(8), 1051-1057.

Diekman, A., Clark, E., Johnston, A., Brown, E., \& Steinberg, M. (2011). Malleability in communal goals and beliefs influences attraction to STEM careers: Evidence for a goal congruity perspective. Journal of Personality and Social Psychology, 101(5), 902-902.

Diekman, A. B., \& Eagly, A. H. (2008). Of men, women, and motivation: A role congruity account. In J. Y. Shah \& W. L. Gardner (Eds.), Handbook of Motivation Science (pp. 434-447). New York: Guilford. 
Diekman, A., \& Steinberg, M. (2013). Navigating social roles in pursuit of important goals: A communal goal congruity account of STEM pursuits. Social and Personality Psychology Compass, 7(7), 487-501. doi:10.1111/spc3.12042

Diekman, A., Weisgram, E., \& Belanger, A. (2015). New routes to recruiting and retaining women in STEM: Policy implications of a communal goal congruity perspective. Social Issues and Policy Review, 9(1), 52-88. doi:10.1111/sipr.12010

Eagly, A. H., Diekman, A. B., Johannesen-Schmidt, M. C., \& Koenig, A. M. (2004). Gender gaps in sociopolitical attitudes: A social psychological analysis. Journal of Personality and Social Psychology, 87, 796 - 816. doi:10.1037/0022-3514.87.6.796

Eagly, A. H., \& Karau, S. J. (2002). Role congruity theory of prejudice toward female leaders. Psychological Review, 109, 573-598. doi:10.1037/0033-295X.109.3.573

Estrada, M., Hernandez, P., Schultz, P. (2018). A longitudinal study of how quality mentorship and research experience integrate underrepresented minorities into STEM careers. $C B E$ Life Sciences Education, 17(1), 9. doi:10.1187/cbe.17-04-0066

Estrada, M., Woodcock, A., Hernandez, P.R., \& Schultz, P.W. (2011). Toward a model of social influence that explains minority student integration into the scientific community. Journal of Educational Psychology, 103(1), 206-222. doi:10.1037/a0022809

Estrada, M., Woodcock, A., \& Schultz, P. (2014). Tailored panel management: A theory-based approach to building and maintaining participant commitment to a longitudinal study. Evaluation Review, 38(1), 3-28.

Fabert, N., \& Bernstein, B. (2009). Women's attrition from STEM doctoral programs: Reflections from non-completers. Toronto: American Psychological Association. 
Fuesting, M., Diekman, A., \& Hudiburgh, L. (2017). From classroom to career: The unique role of communal processes in predicting interest in STEM careers. Social Psychology of Education: An International Journal, 20(4), 875-896. doi:10.1007/s11218-017-9398-6

Garibay, J. (2018). Beyond traditional measures of STEM success: Long-term predictors of social agency and conducting research for social change. Research in Higher Education, 59(3), 349-381.

Garson, G. (2020). Multilevel modeling : Applications in stata, ibm spss, sas, $r$, \& hlm. Thousand Oaks, California: SAGE.

Gibbs, K., \& Griffin, K. (2013). What do I want to be with my PhD? The roles of personal values and structural dynamics in shaping the career interests of recent biomedical science PhD graduates. CBE-Life Sciences Education, 12(4), 711-23. doi:10.1187/cbe.13-02-0021

Glass, J., Sassler, S., Levitte, Y., \& Michelmore, K. (2013). What's so special about stem? A comparison of women's retention in stem and professional occupations. Social Forces, 92(2), 723-756.

Griffin, K., Bennett, J., Staples, C., Robinson, T., \& Gibbs, K. (2015). "Respect me for my science: A bourdieuian analysis of women scientists" interactions with faculty and socialization into science. Journal of Women and Minorities in Science and Engineering, 21(2), 159-179. doi:10.1615/JWomenMinorScienEng.2015011143

Herrmann, S. D., Adelman, R. M., Bodford, J. E., Graudejus, O., Okun, M. A., \& Kwan, V. S. Y. (2016). The Effects of a Female Role Model on Academic Performance and Persistence of Women in STEM Courses. Basic and Applied Social Psychology, 38(5), 258-268. doi:10.1080/01973533.2016.1209757 
Hernandez, P., Schultz, P., Estrada, M., Woodcock, A., \& Chance, R. (2013). Sustaining optimal motivation: A longitudinal analysis of interventions to broaden participation of underrepresented students in STEM. Journal of Educational Psychology, 105(1). doi:10.1037/a0029691

Hill, C., Corbett, C., \& St. Rose, A. (2010). Why so few? Women in science, technology, engineering, and mathematics. American Association of University Women Report.

Kelman, H. (2006). Interests, relationships, identities: Three central issues for individuals and groups in negotiating their social environment. Annual Review of Psychology, 57(1), 126. doi:10.1146/annurev.psych.57.102904.190156

Kokkelenberg, E.C., and Sinha, E. (2010). Who succeeds in STEM studies? An analysis of Binghamton University undergraduate students. Economics of Education Review, 29(6): 935- 946. doi:10.1016/j.econedurev.2010.06.016

Lippa, R. (1998). Gender-related individual differences and the structure of vocational interests: The importance of the people-things dimension. Journal of Personality and Social Psychology, 74, 996 -1009. doi:10.1037/0022-3514.74.4.996

Lowell, B.L., Salzman, H., Bernstein, H., and Henderson, E. (2009). Steady as she goes? Three generations of students through the science and engineering pipeline. Paper presented at the Annual Meetings of the Association for Public Policy Analysis and Management, Washington, DC.

National Science Board. (2018). Science and Engineering Indicators 2018. Arlington, VA: National Science Foundation (NSB-2018-1).

National Science Foundation, National Center for Science and Engineering Statistics. 2019. Women, Minorities, and Persons with Disabilities in Science and Engineering: 2019. 
Special Report NSF 19-304. Alexandria, VA. Available at www.nsf.gov/statistics/wmpd/.

Nielsen, M. W., Alegria, S., Börjeson, L., Etzkowitz, H., Falk-Krzesinski, H. J., Joshi, A., Schiebinger, L. (2017). Opinion: gender diversity leads to better science. Proceedings of the National Academy of Sciences of the United States of America, 114(8), 1740-1742. http://doi.org.www.libproxy.wvu.edu/10.1073/pnas.1700616114

President's Council of Advisors on Science and Technology (PCAST). (2012). Engage to Excel: Producing One Million Additional College Graduates with Degrees in Science, Technology, Engineering, and Mathematics. Washington, DC: Author.

Pöhlmann, K. (2001). Agency- and communion-orientation in life goals: Impacts on goal pursuit strategies and psychological well-being. In P. Schmuck \& K. M. Sheldon (Eds.), Life goals and well-being: Towards a positive psychology of human striving (pp. 68 - 84). Seattle, WA: Hogrefe \& Huber

Rudman, L., \& Glick, P. (2001). Prescriptive gender stereotypes and backlash toward agentic women. Journal of Social Issues, 57(4), 743-762. doi:10.1111/0022-4537.00239

Schultz, P.W., Hernandez, P.R., Woodcock, A., Estrada, M., Chance, R.C., Aguilar, M., and Serpe, R.T. (2011). Patching the pipeline: Reducing educational disparities in the sciences through minority training programs. Educational Evaluation and Policy Analysis, 33(1), 95-114. doi:10.3102/0162373710392371

Shauman, K.A. (2017). Gender differences in the early employment outcomes of STEM doctorates. Social Sciences 6.

Shaw, E.J., and Barbuti, S. (2010). Patterns of persistence in intended college major with a focus on STEM majors. The National Academic Advising Association Journal, 30(2): 19-34. 
Smith, J., Brown, E., Thoman, D., \& Deemer, E. (2015). Losing its expected communal value: How stereotype threat undermines women's identity as research scientists. Social Psychology of Education: An International Journal, 18(3), 443-466. doi:10.1007/s11218-015-9296-8

Snijders, T.A.B. \& Bosker, R.J. (2012). Multilevel analysis: An introduction to basic and advanced multilevel modeling ( $2^{\text {nd }}$ ed.) Thousand Oaks, CA: Sage.

Snyder, T.D., Dillow, S.A., \& Hoffman, C.M. (2009). Digest of education statistics, 2008 (NCES 2009-020). Washington, DC: U.S. Department of Education, National Center for Education Statistics, Institute of Education Sciences.

Stets, J., Brenner, P., Burke, P., \& Serpe, R. (2017). The science identity and entering a science occupation. Social Science Research, 64, 1-14. doi:10.1016/j.ssresearch.2016.10.016

Thoman, D., Arizaga, J., Story, T., Soncuya, G., \& Smith, J. (2014). The grass is greener in nonscience, technology, engineering, and math classes: Examining the role of competing belonging to undergraduate women's vulnerability to being pulled away from science. Psychology of Women Quarterly, 38(2), 246-258. doi:10.1177/0361684313499899

Woodcock, A., Hernandez, P., Estrada, M., \& Schultz, P. (2012). The consequences of chronic stereotype threat: Domain disidentification and abandonment. Journal of Personality and Social Psychology, 103(4), 635-635.

Woodcock, A., Hernandez, P. R., \& Schultz, P. W. (2015). Diversifying science: intervention programs moderate the effect of stereotype threat on motivation and career choice. Social Psychological and Personality Science, 7(2), 184-192. https://doi.org/10.1177/1948550615608401 
PERSISTENCE OF WOMEN IN STEM

Table 1.

Demographic Totals for Participants

\begin{tabular}{|c|c|c|}
\hline & $N$ & $\%$ \\
\hline \multicolumn{3}{|l|}{ Ethnic Background } \\
\hline European & 337 & 69.6 \\
\hline African & 56 & 11.6 \\
\hline Asian & 36 & 7.4 \\
\hline Latina & 43 & 8.9 \\
\hline Native American/Pacific Islander/First Nation & 54 & 11.2 \\
\hline Other & 8 & 1.7 \\
\hline \multicolumn{3}{|l|}{ University Attending } \\
\hline Colorado College & 33 & 6.8 \\
\hline Colorado State University & 81 & 16.7 \\
\hline Metropolitan State University of Denver & 32 & 6.6 \\
\hline North Carolina A\&T University & 29 & 6 \\
\hline North Carolina State University & 52 & 10.7 \\
\hline University of Colorado - Boulder & 85 & 17.5 \\
\hline University of North Carolina - Charlotte & 61 & 12.6 \\
\hline University of South Carolina & 67 & 13.8 \\
\hline University of Wyoming & 44 & 9.1 \\
\hline \multicolumn{3}{|l|}{ Initial Semester of Participation } \\
\hline Fall Semester First Year & 250 & 51.4 \\
\hline Fall Semester Sophomore Year & 228 & 46.9 \\
\hline Fall Semester Junior Year & 1 & 0.2 \\
\hline Fall Semester Senior Year & 5 & 1 \\
\hline STEM major & 482 & 99.2 \\
\hline Family Income $\$ 50,000$ or less & 132 & 26.4 \\
\hline Family Income over $\$ 100,000$ & 140 & 28.1 \\
\hline
\end{tabular}


Running head: PERSISTENCE OF WOMEN IN STEM

Table 2.

Descriptive Statistics for Orientation Measures and Persistence Waves 2 through 4

\begin{tabular}{|c|c|c|c|c|c|c|c|c|c|c|c|c|}
\hline & \multicolumn{4}{|c|}{ Wave 2} & \multicolumn{4}{|c|}{ Wave 3} & \multicolumn{4}{|c|}{ Wave 4} \\
\hline & $N$ & $M(S D)$ & $S$ & K & $N$ & $M(S D)$ & $S$ & K & $N$ & $M(S D)$ & $S$ & K \\
\hline $\begin{array}{l}\text { Science } \\
\text { Self-Efficacy }\end{array}$ & 212 & $5.11(1.04)$ & -0.24 & -0.31 & 198 & $5.31(1.06)$ & -1.02 & 1.97 & 364 & $5.37(1.07)$ & -0.47 & 0.04 \\
\hline Science Identity & 211 & $4.90(1.23)$ & -0.29 & -0.14 & 205 & $4.83(1.51)$ & -0.51 & -0.26 & 363 & $4.91(1.36)$ & -0.63 & 0.09 \\
\hline $\begin{array}{l}\text { Agentic } \\
\text { Value } \\
\text { Affordance }\end{array}$ & 209 & $5.24(1.01)$ & -0.12 & -0.26 & 203 & $5.70(0.95)$ & -0.67 & 0.26 & 359 & $5.60(1.01)$ & -0.5 & -0.23 \\
\hline $\begin{array}{l}\text { Communal Value } \\
\text { Affordance }\end{array}$ & 209 & $5.91(1.13)$ & -1.14 & 0.88 & 203 & $5.90(1.03)$ & -0.85 & 0.2 & 359 & $5.98(1.03)$ & -1.08 & 0.82 \\
\hline $\begin{array}{l}\text { Scientific } \\
\text { Community } \\
\text { Values }\end{array}$ & 209 & $6.00(1.03)$ & -1.05 & 1.06 & 198 & $6.12(1.00)$ & -1.83 & 4.46 & 363 & $6.26(0.86)$ & -1.92 & 5.96 \\
\hline $\begin{array}{l}\text { Agentic Value } \\
\text { Endorsement }\end{array}$ & - & - & - & - & 196 & $5.27(1.17)$ & -0.55 & 0.17 & 359 & $4.96(1.22)$ & -0.3 & -0.19 \\
\hline $\begin{array}{l}\text { Communal Value } \\
\text { Endorsement }\end{array}$ & - & - & - & - & 196 & $6.05(0.96)$ & -1.1 & 0.63 & 359 & $5.97(1.10)$ & -1.37 & 2.02 \\
\hline $\begin{array}{l}\text { Persistence } \\
\text { Intentions }\end{array}$ & 205 & $6.11(1.08)$ & -1.76 & 4.12 & 205 & $5.71(1.38)$ & -1.32 & 1.58 & 387 & $5.81(1.39)$ & -1.51 & 2.33 \\
\hline
\end{tabular}


PERSISTENCE OF WOMEN IN STEM

Table 2 (continued).

Descriptive Statistics for Orientation Measures and Persistence Waves 5 through 8

\begin{tabular}{|c|c|c|c|c|c|c|c|c|c|c|c|c|c|c|c|c|}
\hline & \multicolumn{4}{|c|}{ Wave 5} & \multicolumn{4}{|c|}{ Wave 6} & \multicolumn{4}{|c|}{ Wave 7} & \multicolumn{4}{|c|}{ Wave 8} \\
\hline & $N$ & $M(S D)$ & $S$ & K & $N$ & $M(S D)$ & $s$ & K & $N$ & $M(S D)$ & $S$ & $K$ & $N$ & $M(S D)$ & $S$ & $K$ \\
\hline $\begin{array}{l}\text { Science } \\
\text { Self-Efficacy }\end{array}$ & 370 & $5.29(1.10)$ & -0.56 & 0.21 & 382 & $5.35(1.09)$ & -0.77 & 1 & 378 & $5.37(1.17)$ & -0.87 & 0.91 & 354 & $5.48(1.03)$ & -1.25 & 3.24 \\
\hline Science Identity & 370 & $4.85(1.36)$ & -0.5 & -0.02 & 380 & $4.75(1.57)$ & -0.59 & -0.24 & 378 & $4.73(1.65)$ & -0.44 & -0.69 & 354 & $4.88(1.63)$ & -0.59 & -0.44 \\
\hline $\begin{array}{l}\text { Agentic } \\
\text { Value } \\
\text { Affordance }\end{array}$ & 370 & $5.87(0.96)$ & -0.86 & 0.71 & 382 & $5.89(1.11)$ & -1.07 & 1.09 & 377 & $5.91(1.07)$ & -1.07 & 1.15 & 354 & $5.82(1.25)$ & -1.18 & 1.48 \\
\hline $\begin{array}{l}\text { Communal Value } \\
\text { Affordance }\end{array}$ & 370 & $5.91(1.05)$ & -0.79 & -0.17 & 381 & $5.83(1.21)$ & -1.01 & 0.6 & 377 & $5.87(1.16)$ & -1.03 & 0.69 & 354 & $5.82(1.31)$ & -1.14 & 1.12 \\
\hline $\begin{array}{l}\text { Scientific } \\
\text { Community } \\
\text { Values }\end{array}$ & 370 & $6.25(0.91)$ & -1.94 & 5.97 & 381 & $6.17(0.99)$ & -1.94 & 5.58 & 378 & $6.13(0.96)$ & -1.62 & 3.1 & 353 & $6.17(0.87)$ & -1.31 & 2.07 \\
\hline $\begin{array}{l}\text { Agentic Value } \\
\text { Endorsement }\end{array}$ & 370 & $5.14(1.24)$ & -0.43 & -0.04 & 380 & $6.04(1.14)$ & -1.47 & 2.49 & 377 & $5.61(1.18)$ & -0.76 & 0.37 & 352 & $5.57(1.35)$ & -0.94 & 0.58 \\
\hline $\begin{array}{l}\text { Communal Value } \\
\text { Endorsement }\end{array}$ & 370 & $6.05(1.10)$ & -1.45 & 2.44 & 383 & $6.31(0.98)$ & -1.69 & 3.51 & 377 & $6.31(1.00)$ & -1.63 & 2.22 & 352 & $6.23(1.07)$ & -1.56 & 2.41 \\
\hline $\begin{array}{l}\text { Persistence } \\
\text { Intentions }\end{array}$ & 388 & $5.52(1.38)$ & -1.04 & 0.8 & 401 & $5.44(1.57)$ & -1.23 & 0.95 & 385 & $5.38(1.50)$ & -1.14 & 1.02 & 365 & $5.36(1.60)$ & -1.1 & 0.64 \\
\hline
\end{tabular}


Table 3.

Correlations for Level-1 and Level-2 Variables

\begin{tabular}{|c|c|c|c|c|c|c|c|c|c|}
\hline Measure & 1 & 2 & 3 & 4 & 5 & 6 & 7 & 8 & 9 \\
\hline $\begin{array}{l}\text { 1. Semester } \\
\text { in School }\end{array}$ & - & & & & & & & & \\
\hline $\begin{array}{l}\text { 2. Science } \\
\text { Efficacy }\end{array}$ & $.08 * *$ & - & & & & & & & \\
\hline $\begin{array}{l}\text { 3. Science } \\
\text { Identity }\end{array}$ & .01 & $.43 * *$ & - & & & & & & \\
\hline $\begin{array}{l}\text { 4. Scientific } \\
\text { Community } \\
\text { Values }\end{array}$ & .04 & $.29 * *$ & $.42 * *$ & - & & & & & \\
\hline $\begin{array}{l}\text { 5. Agentic Value } \\
\text { Endorsement }\end{array}$ & $.14 * *$ & $.13^{* *}$ & $.11^{* *}$ & $.10 * *$ & - & & & & \\
\hline $\begin{array}{l}\text { 6. Communal } \\
\text { Value } \\
\text { Endorsement }\end{array}$ & $.08 * *$ & $.10 * *$ & $.09 * *$ & $.13 * *$ & $.14^{* *}$ & - & & & \\
\hline $\begin{array}{l}\text { 7. Agentic Value } \\
\text { Affordance }\end{array}$ & $.11 * *$ & $.21 * *$ & $.28 * *$ & $.29 * *$ & $.41 * *$ & $.17 * *$ & - & & \\
\hline $\begin{array}{l}\text { 8. Communal } \\
\text { Value } \\
\text { Affordance }\end{array}$ & -.04 & $.19 * *$ & $.26 * *$ & $.29 * *$ & $.13 * *$ & $.41 * *$ & $.46 * *$ & - & \\
\hline $\begin{array}{l}\text { 9. Persistence } \\
\text { Intentions }\end{array}$ & $-.09 * *$ & $.27 * *$ & $.60 * *$ & $.36 * *$ & .03 & .03 & $.23 * *$ & $.24 * *$ & - \\
\hline
\end{tabular}


Running head: PERSISTENCE OF WOMEN IN STEM

\section{Table 4.}

Time Models Equations Level -1 and -2

Model Equations

Time Models

$$
\text { Level -1 }
$$

Level-2

M1

$$
\text { PERSISTENCE }_{\mathrm{ti}}=\pi_{0 \mathrm{i}}+\mathrm{e}_{\mathrm{ti}}
$$

$\pi_{0 \mathrm{i}}=\beta_{00}+\mathrm{r}_{0 \mathrm{i}}$

M2

$$
\begin{aligned}
& \text { PERSISTENCE }_{\mathrm{ti}}=\pi_{0 \mathrm{i}}+\pi_{1 \mathrm{i}} *\left(\mathrm{SEMCEN}_{\mathrm{ti}}\right)+\mathrm{e}_{\mathrm{ti}} \pi_{0 \mathrm{i}}=\beta_{00}+\mathrm{r}_{0 \mathrm{i}} \\
& \pi_{1 \mathrm{i}}=\beta_{10}+\mathrm{r}_{1 \mathrm{i}}
\end{aligned}
$$

PERSISTENCE $_{\mathrm{ti}}=\pi_{0 \mathrm{i}}+\pi_{1 \mathrm{i}} *\left(\mathrm{SEMCEN}_{\mathrm{ti}}\right)+$

$\pi_{0 \mathrm{i}}=\beta_{00}+\mathrm{r}_{0 \mathrm{i}}$ $\pi_{2 i} *\left(S^{2} M Q U A D_{t i}\right)+e_{t i}$

$\pi_{1 \mathrm{i}}=\beta_{10}+\mathrm{r}_{1 \mathrm{i}}$

$\pi_{2 \mathrm{i}}=\beta_{20}+\mathrm{r}_{2 \mathrm{i}}$

M4

$$
\begin{array}{cl}
\text { PERSISTENCE }_{\mathrm{ti}}=\pi_{0 \mathrm{i}}+\pi_{1 \mathrm{i}} *\left(\mathrm{SEMCEN}_{\mathrm{ti}}\right)+ & \pi_{0 \mathrm{i}}=\beta_{00}+\mathrm{r}_{0 \mathrm{i}} \\
\pi_{2 \mathrm{i}} *\left(\mathrm{SEMQUAD}_{\mathrm{ti}}\right)+\mathrm{e}_{\mathrm{ti}} & \pi_{1 \mathrm{i}}=\beta_{10}+\mathrm{r}_{1 \mathrm{i}} \\
& \pi_{2 \mathrm{i}}=\beta_{20}
\end{array}
$$

$$
\begin{array}{cl}
\text { PERSISTENCE }_{\mathrm{i}}=\pi_{0 \mathrm{i}}+\pi_{1 \mathrm{i}} *\left(\mathrm{SEMCEN}_{\mathrm{ti}}\right)+ & \pi_{0 \mathrm{i}}=\beta_{00}+\mathrm{r}_{0 \mathrm{i}} \\
\pi_{2 \mathrm{i}} *\left(\operatorname{SEMQUAD}_{\mathrm{ti}}\right)+\pi_{3 \mathrm{i}} *\left(\operatorname{SEMCUBED~}_{\mathrm{ti}}\right)+\mathrm{e}_{\mathrm{ti}} & \pi_{1 \mathrm{i}}=\beta_{10}+\mathrm{r}_{1 \mathrm{i}} \\
& \pi_{2 \mathrm{i}}=\beta_{20} \\
& \pi_{3 \mathrm{i}}=\beta_{30}+\mathrm{r}_{3 \mathrm{i}}
\end{array}
$$

M6

$$
\begin{aligned}
& \text { PERSISTENCE }_{\mathrm{ti}}=\pi_{0 \mathrm{i}}+\pi_{1 \mathrm{i}} *\left(\text { SEMCEN }_{\mathrm{ti}}\right)+ \\
& \pi_{2 \mathrm{i}} *\left(\text { SEMQUAD }_{\mathrm{ti}}\right)+\pi_{3 \mathrm{i}} *\left(\text { SEMCUBED }_{\mathrm{ti}}\right)+\mathrm{e}_{\mathrm{ti}}
\end{aligned}
$$$$
\pi_{0 \mathrm{i}}=\beta_{00}+\mathrm{r}_{0 \mathrm{i}}
$$

$\pi_{1 \mathrm{i}}=\beta_{10}+\mathrm{r}_{1 \mathrm{i}}$

$\pi_{2 \mathrm{i}}=\beta_{20}$

$\pi_{3 \mathrm{i}}=\beta_{30}$

M7

$$
\begin{gathered}
\text { PERSISTENCE }_{\mathrm{ti}}=\pi_{0 \mathrm{i}}+\pi_{1 \mathrm{i}} *\left(\text { SEMCEN }_{\mathrm{ti}}\right)+ \\
\pi_{2 \mathrm{i}} *\left(\text { SEMQUAD }_{\mathrm{ti}}\right)+\pi_{3 \mathrm{i}} *\left(\text { SEMCUBED }_{\mathrm{ti}}\right)+ \\
\pi_{4 \mathrm{i}} *\left(\text { SEMQUART }_{\mathrm{ti}}\right)+\mathrm{e}_{\mathrm{ti}}
\end{gathered}
$$

$\pi_{0 \mathrm{i}}=\beta_{00}+\mathrm{r}_{0 \mathrm{i}}$

$\pi_{1 \mathrm{i}}=\beta_{10}+\mathrm{r}_{1 \mathrm{i}}$

$\pi_{2 \mathrm{i}}=\beta_{20}$

$\pi_{3 \mathrm{i}}=\beta_{30}$

$\pi_{4 \mathrm{i}}=\beta_{40}+\mathrm{r}_{4 \mathrm{i}}$

M8

$$
\begin{array}{ll}
\text { PERSISTENCE }_{\mathrm{ti}}=\pi_{0 \mathrm{i}}+\pi_{1 \mathrm{i}} *\left(\mathrm{SEMCEN}_{\mathrm{ti}}\right)+ & \pi_{0 \mathrm{i}}=\beta_{00}+\mathrm{r}_{0 \mathrm{i}} \\
\pi_{2 \mathrm{i}} *\left(\text { SEMQUAD }_{\mathrm{ti}}\right)+\pi_{3 \mathrm{i}} *\left(\text { SEMCUBED }_{\mathrm{ti}}\right)+ & \pi_{1 \mathrm{i}}=\beta_{10}+\mathrm{r}_{1 \mathrm{i}} \\
\pi_{4 \mathrm{i}} *\left(\mathrm{SEMQUART}_{\mathrm{ti}}\right)+\mathrm{e}_{\mathrm{ti}} & \pi_{2 \mathrm{i}}=\beta_{20} \\
& \pi_{3 \mathrm{i}}=\beta_{30} \\
& \pi_{4 \mathrm{i}}=\beta_{40}
\end{array}
$$




\section{Table 5.}

SEM Slope and Intercept Models Equations Level -1 and -2

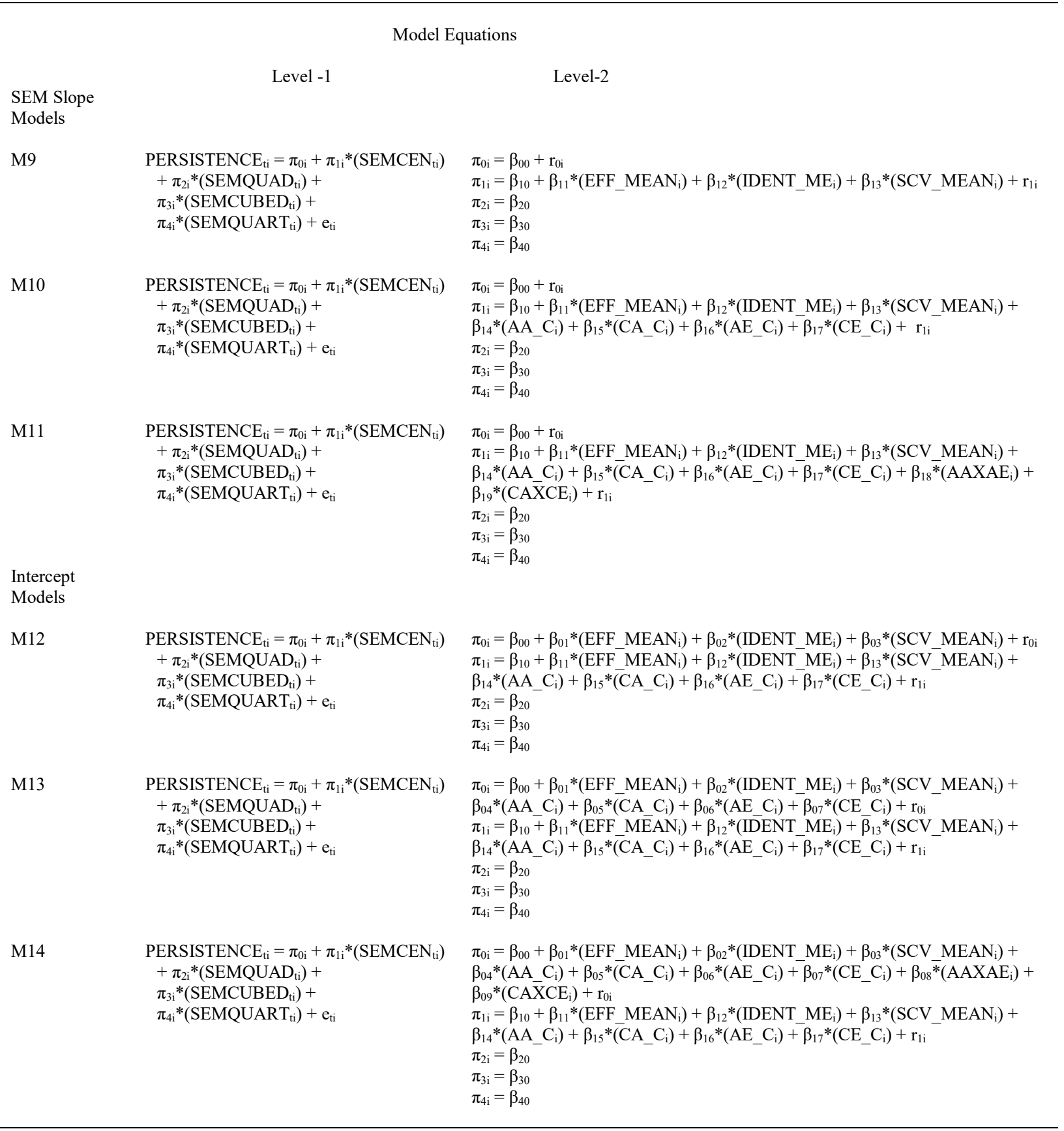


PERSISTENCE OF WOMEN IN STEM

Table 6 .

Model Fit Statistics for Persistence

\begin{tabular}{|c|c|c|c|c|c|c|c|}
\hline Models & Model Comparison & Deviance & Parameters & $\Delta \chi^{2}(d f)$ & $p$ & $A I C$ & $B I C$ \\
\hline \multicolumn{8}{|l|}{ Time Models } \\
\hline M1 & & 6278.36 & 3 & & & 6284.36 & 6296.54 \\
\hline M2 & 1 vs. 2 & 6150.60 & 6 & $127.76(3)$ & 0.000 & 6162.60 & 6186.96 \\
\hline M3 & 2 vs. 3 & 6130.55 & 10 & $20.05(4)$ & 0.000 & 6150.55 & $6191.15^{*}$ \\
\hline M4 & 2 vs. 4 & 6143.22 & 7 & $7.38(1)$ & 0.007 & 6157.22 & 6185.64 \\
\hline M5 & 4 vs. 5 & 6128.78 & 11 & $14.44(4)$ & 0.006 & 6150.78 & $6195.44^{*}$ \\
\hline M6 & 4 vs. 6 & 6141.67 & 8 & $1.55(1)$ & 0.213 & 6157.67 & 6190.15 \\
\hline M7 & 4 vs. 7 & 6124.72 & 12 & $18.5(5)$ & 0.002 & 6148.72 & $6197.44 *$ \\
\hline M8 & 4 vs. 8 & 6136.84 & 9 & $6.38(2)$ & 0.041 & 6154.84 & 6191.38 \\
\hline \multicolumn{8}{|l|}{ Slope Models } \\
\hline M9 & 8 vs. 9 & 5956.93 & 12 & $179.91(3)$ & 0.000 & 5980.93 & 6029.65 \\
\hline M10 & 9 vs. 10 & 5929.40 & 16 & $27.53(4)$ & 0.000 & 5955.40 & 6026.36 \\
\hline M11 & 10 vs. 11 & 5929.29 & 18 & $0.11(2)$ & 0.947 & 5951.29 & 6038.37 \\
\hline \multicolumn{8}{|c|}{ Intercept Models } \\
\hline M12 & 10 vs. 12 & 5782.31 & 19 & $147.09(3)$ & 0.000 & 5806.31 & 5897.45 \\
\hline M13 & 12 vs. 13 & 5770.09 & 23 & $12.22(4)$ & 0.016 & 5796.09 & 5909.47 \\
\hline M14 & 13 vs. 14 & 5768.55 & 25 & $1.54(2)$ & 0.465 & 5790.55 & 5920.05 \\
\hline
\end{tabular}

*Added parameters were non-significant in the model; therefore, the model build was rejected. 


\section{Table 7.}

Final Model Estimates for Persistence and Orientation Measures across Time

\begin{tabular}{|c|c|c|c|c|c|}
\hline Fixed Effects & Coefficient & S.E. & t-ratio & df & p-value \\
\hline \multicolumn{6}{|l|}{ For Intercept, $\pi_{0}$} \\
\hline Intercept, $\beta_{00}$ & 6.04 & 0.07 & 80.77 & 421 & $<0.001$ \\
\hline Efficacy, $\beta_{01}$ & 0.02 & 0.08 & 0.21 & 421 & 0.84 \\
\hline Identity, $\beta_{02}$ & 0.51 & 0.06 & 8.64 & 421 & $<0.001$ \\
\hline Scientific Comm.Values, $\beta_{03}$ & 0.44 & 0.09 & 4.97 & 421 & $<0.001$ \\
\hline Agentic Afford., $\beta_{04}$ & -0.19 & 0.12 & -1.55 & 421 & 0.12 \\
\hline Communal Afford., $\beta_{05}$ & -0.04 & 0.10 & -0.40 & 421 & 0.69 \\
\hline Agentic Endorse., $\beta_{06}$ & -0.09 & 0.07 & -1.33 & 421 & 0.18 \\
\hline Communal Endorse., $\beta_{07}$ & 0.01 & 0.08 & 0.17 & 421 & 0.87 \\
\hline \multicolumn{6}{|l|}{ For Time slope, $\pi_{l}$} \\
\hline Intercept, $\beta_{10}$ & -0.41 & 0.16 & -2.60 & 421 & 0.01 \\
\hline Efficacy, $\beta_{11}$ & 0.01 & 0.02 & 0.30 & 421 & 0.77 \\
\hline Identity, $\beta_{12}$ & 0.02 & 0.01 & 1.58 & 421 & 0.12 \\
\hline Scientific Comm.Values, $\beta_{13}$ & -0.05 & 0.02 & -2.14 & 421 & 0.03 \\
\hline Agentic Afford., $\beta_{14}$ & 0.10 & 0.03 & 3.19 & 421 & 0.00 \\
\hline Communal Afford., $\beta_{15}$ & 0.03 & 0.03 & 1.02 & 421 & 0.31 \\
\hline Agentic Endorse., $\beta_{16}$ & -0.02 & 0.02 & -1.18 & 421 & 0.24 \\
\hline Communal Endorse., $\beta_{17}$ & -0.05 & 0.02 & -2.34 & 421 & 0.02 \\
\hline \multicolumn{6}{|l|}{ For Quad Time slope, $\pi_{2}$} \\
\hline Intercept, $\beta_{20}$ & 0.22 & 0.12 & 1.85 & 1176 & 0.07 \\
\hline \multicolumn{6}{|l|}{ For Cubic Time slope, $\pi_{3}$} \\
\hline Intercept, $\beta_{30}$ & -0.06 & 0.03 & -1.94 & 1176 & 0.05 \\
\hline \multicolumn{6}{|l|}{ For Quartic Time slope, $\pi_{4}$} \\
\hline Intercept , $\beta_{40}$ & 0.01 & 0.00 & 2.09 & 1176 & 0.04 \\
\hline \multirow[t]{4}{*}{ Random Effects } & SD & Variance & df & $\chi^{2}$ & p-value \\
\hline & 0.75 & 0.57 & 407 & 815.80 & $<0.001$ \\
\hline & 0.15 & 0.02 & 407 & 651.74 & $<0.001$ \\
\hline & 0.83 & 0.69 & & & \\
\hline
\end{tabular}


PERSISTENCE OF WOMEN IN STEM

Figure 3.

Persistence Intentions across Time

\section{Persistence Intentions}

7

6

\begin{tabular}{rrrrrr}
5.94 & 5.8 & 5.83 & & & \\
\hline 5.52 & 5.968 & 5.44 & 5.5 & 5.57 \\
\hline
\end{tabular}

5

4

\begin{tabular}{|c|c|c|c|c|c|c|}
\hline Year 1 Spring & Year 2 Fall & Year 2 Spring & Year $3 \mathrm{Fal}$ & Year 3 Spring & Year 4 Fall & Year 4 Spring \\
\hline
\end{tabular}

